\title{
How Can Medical Students Gain Exposure to Plastic Surgery during Medical School?
}

\author{
Yangmyung $\mathrm{Ma}^{1}{ }^{10}$ \\ ${ }^{1}$ School of Medicine and Surgery, Hull York Medical School, University \\ Rd, Heslington, York, United Kingdom \\ Indian J Plast Surg 2022;55:117-118.
}

Address for correspondence Yangmyung Ma, MBBS, 7 Bellwood Road, Birmingham, B31 1QB, United Kingdom (e-mail: yangmyung.ma2@nhs.net).

Reforms in medical schools have resulted in students spending less time in surgical rotations, particularly plastic surgery, as students often place learning priorities on specialties that are examination-heavy. ${ }^{1}$ This is despite studies demonstrating that the acquisition of plastic surgery knowledge made better clinicians. ${ }^{2}$ The continuation of this paradigm could potentially discourage medical students from pursuing a career in this specialty, affecting both its sustainability and the value it brings to clinical practice.

Increasing exposure must therefore be achieved outside the curriculum, initiated by students. This is achieved through the formation of a Plastic Surgery Society that provides an environment for students to liaise with the local plastic surgery department and network with plastic surgery organizations to create a domino effect of engagement. A society can be formed based on an acronym that the author has devised: INSPIRE. I stands for Initiate, whereby the student must begin forming the foundation of the society. This includes forming a committee before creating a logo and name of the society. $\mathrm{N}$ stands for Network. This is when the newly formed committee contacts the local plastic surgery unit or various consultants around the region to help oversee and aid the society. Honorary positions can be appointed to consultants which may encourage greater responsibility and engagement. Networking also includes contacting organizations for valuable resources and information. S stands for Schedule. To run a successful society, events must be scheduled, ranging from inspirational talks given by consultants to journal clubs where students can critically appraise papers together to increase knowledge of the specialty. More practical approaches are also successful in gaining exposure through organizing suturing, microsurgery, or cadaveric dissection courses, which allow students to directly experience the work of plastic surgeons. It is important that events, especially skills' workshops, are held regularly along-

published online

February 12, 2022
DOI https://doi.org/ 10.1055/s-0041-1740084. ISSN 0970-0358. side teaching sessions-a busy society makes a successful society. The aim of these events should be to improve interaction with faculty, opportunities for learning, and undertaking of projects. The society can also encourage its members to take up special interest programs within the medical school and electives in plastic surgery to further foster interest and commitment. P stands for Promote. This is achieved through using various communication platforms such as mailing lists and social media. Students can send emails of upcoming events and reminders to all students, advertise events on medical school newsletters, and create societal posters to distribute in hospital and medical school bulletin boards. It also provides a means to communicate efficiently any valuable resources and collaborate with other societies and organizations, further promoting the society and plastic surgery. I stands for Integrate. This requires students to integrate personally with the local plastic surgery team. To achieve this, the society can form mentorship schemes, whereby students are assigned to a particular consultant. Students can then hopefully gain operative experience, obtain an insight into their future careers, and be given more opportunities to undertake projects. Integration can also be attained in medical schools through electing plastic surgery representatives within each year, so that all students have a more personalized point of contact. $R$ stands for Reform. Reform is vital for progress, and this can be achieved through feedback forms. They can be handed out after every event to students and consultants, so that future events can be improved. Acting on feedback shows opinions and ideas are being heard, which improves engagement and exposure to plastic surgery. Finally, E stands for Expand. Expansion garners exposure on a larger scale and illustrates members of the society's commitment to sustainability. This is accomplished through encouraging students to become student committee members of national Plastic Surgery organizations. If these positions are (c) 2022. Association of Plastic Surgeons of India. All rights reserved. This is an open access article published by Thieme under the terms of the Creative Commons Attribution-NonDerivative-NonCommercial-License, permitting copying and reproduction so long as the original work is given appropriate credit. Contents may not be used for commercial purposes, or adapted, remixed, transformed or built upon. (https://creativecommons.org/ licenses/by-nc-nd/4.0/)

Thieme Medical and Scientific Publishers Pvt. Ltd., A-12, 2nd Floor, Sector 2, Noida-201301 UP, India 
obtained, this opens doors to more teaching material and networking opportunities outside the local area along with opportunity to join research, audits, and to join teams going abroad for reconstructive surgery. Furthermore, Plastic Surgery societies in all medical schools can collaborate to create a national plastic surgery conference. This will help students to interact with more like-minded people and also learn from leading plastic surgeons, providing greater incentive for students to attend and gain exposure.

Plastic surgery has always evolved throughout history and is the specialty at the forefront of innovation. ${ }^{3}$ To continue this tradition of innovation sustainably, the specialty must also adapt to work symbiotically with students by providing relevant resources for learning and improving ways of communicating. By working closely, students can explore their interests earlier on, leading to publications and posters that set the foundation of yielding new ideas that carry the specialty forward.

\section{Conflict of Interest}

None declared.

\section{References}

1 Lemon TI. Anglo-French comparison study of plastic surgery teaching. J Res Med Educ Ethics. 2014;4:203-208

2 Robertson B, Jones C, Sivathasan N, Chew B. The need for plastic surgery in the medical undergraduate curriculum. International Journal of Orthoplastic Surgery. 2018;1(01):13-17

$3 \mathrm{Ng}$ NY, Twoon M. Simple ways to improve undergraduate plastic surgery education. Indian J Plast Surg 2015;48(01):96-97 